Neth. J. Pl. Path. 91 (1985) 235-247

\title{
Damage components of powdery mildew in winter wheat
}

\author{
R. RABBINGE, I.T.M. JORRITSMA and J. SCHANS
}

Department of Theoretical Production Ecology, Agricultural University, P.O.Box 430, 6700 AK Wageningen, the Netherlands

Accepted 3 May 1985

\begin{abstract}
The photosynthesis and transpiration rates of winter wheat leaves were measured at different developmental stages and at various levels of mildew infection. Even at low levels of infection, circa $4 \%$ leaf area being covered, both the assimilation and transpiration rates at light satiation were considerably reduced. Light use efficiency and dark respiration were not significantly affected. The physiological background of these effects was analysed by photosynthesis measurements at different external $\mathrm{CO}_{2}$ concentrations. It was shown that the carboxylation resistance was increased due to mildew infection and that stomatal resistance, boundary layer resistance and transport resistance in the mesophyll were only indirectly affected.

A simulation model was used to compute the consequences of these effects on daily growth rate of a winter wheat canopy at different development stages and with different levels of mildew severity. These computations show that a low infection level may result in a considerable reduction of the crop growth rate. This effect was more pronounced when the sky was clear than overcast.
\end{abstract}

Additional keywords: Erysiphe graminis, photosynthesis, transpiration, leaf resistance, simulation, carboxylation resistance.

\section{Introduction}

Powdery mildew, Erysiphe graminis D.C. ex Mérat f.sp. tritici, is a common disease of wheat and may cause serious yield loss. Large and Doling $(1962,1963)$ state that damage is proportional to the square root of leaf area covered by mildew at flowering, development stage DC 60 (Decimal Code, Zadoks et al., 1974).

Recently R.A. Daamen (in prep.) demonstrated in field experiments that low levels of severity (circa 4\% leaf area covered with mildew) occurring before flowering (DC 60 ), may already cause considerable yield loss (circa 10\%). To explain this strong effect on yield and to gain an insight in the crop-physiological background of damage, an analysis of the effects of mildew on various physiological characteristics was carried out. To evaluate the consequences for crop growth, simulation studies were performed.

Several, mainly qualitative, effects of mildew on the growth of cereals have been demonstrated. Photosynthesis (Paulech, 1966; Scott and Smillie, 1966) and transpiration (Martin et al., 1975; Priehradny, 1978; Ayres, 1978) are hampered and leaf senescence is promoted (Finney, 1979). Growth and activity of the roots are affected (Baenziger et al., 1979; Vizarova and Minarçic, 1974). 
Little is known quantitatively about the various damage components of mildew on wheat. Quantitative data are essential to explain yield loss occurring under different field conditions. Detailed studies are then necessary and may lead step by step to that ultimate aim. The objectives of this study were:

1. to determine the quantitative effect of mildew on assimilation, respiration and transpiration rates of wheat plants;

2. to analyse the plant-physiological background of these effects;

3. to compute the consequences of these effects for daily gross assimilation rate and crop growth rate.

\section{Materials and methods}

Plants and inoculation. From a field of winter wheat, cv. Okapi, near Wageningen, plants (development stage DC 13) were transferred on day 5 (Julian day) to Mitscherlich pots $(\phi 28 \mathrm{~cm})$ filled with clay ( $40 \%$ lutum, $8 \mathrm{mg} \mathrm{N} \mathrm{kg}^{-1}$ soil). There were five plants per pot, 160 pots were initiated. Fertilizer was added to the pot soils, at rates of $5.5 \mathrm{~g}$ potassium $(26.5 \% \mathrm{~K})$ and $5.5 \mathrm{~g}$ 'superphosphate' $\left(44 \% \mathrm{PO}_{4}\right)$ per pot. Additional nitrogen fertilizer was applied at a rate of $2 \mathrm{~g} \mathrm{NH}_{4} \mathrm{NO}_{3}$ per pot on days 21,55 and 95. Plants were grown in a glasshouse at a temperature of $16^{\circ} \mathrm{C}$ and $60 \%$ relative humidity. The soil was kept at field capacity. On day 28 all plants were sprayed with triadimefon and maneb against mildew and brown rust infections which appeared in the plants. The control plants needed a second triadimefon treatment on day 61 and a pirimicarb treatment against aphids on day 68 . Phytotoxic or phytostimulating effects of these sprayings were negligible.

Twenty-four hours prior to inoculation mildew infected seedlings were shaken to remove old conidia. On day 49 inoculation was performed by shaking the infector plants above the test plants (development stage DC 30). The inoculated plants were then incubated at $14{ }^{\circ} \mathrm{C}$ and $90 \%$ relative humidity. The environmental conditions for the control plants were changed in the same way. Photosynthesis measurements were started on day 66 (development stage DC 32).

Assimilation, respiration and transpiration rates of flag leaves or youngest leaves of diseased and control plants were measured at development stages between DC 32 and DC 65. The equipment used is described by Louwerse and Van Oorschot (1969). Data on the rate of $\mathrm{CO}_{2}$ uptake and $\mathrm{H}_{2} \mathrm{O}$ production $\left(\mathrm{kg} \mathrm{ha}^{-1} \mathrm{~h}^{-1}\right)$, irradiance $\left(\mathrm{W} \mathrm{m}^{-2}\right.$ ), air temperature $\left({ }^{\circ} \mathrm{C}\right.$ ) and air humidity (mbar) were stored and processed by a microcomputer. Subsequently stomatal resistance $\left(\mathrm{s} \mathrm{m}^{-1}\right)$, internal $\mathrm{CO}_{2}$ concentration of the leaf $\left(\mathrm{mg} \mathrm{m}^{-3}\right)$ and latent heat $\left(\mathrm{W} \mathrm{m}^{-2}\right)$ were calculated. At both development stages two series of measurements were performed. In series I a light response curve at a constant ambient $\mathrm{CO}_{2}$ concentration of $340 \mathrm{mg} \mathrm{m}^{-3}$ was measured. Irradiance (visible range $400-700 \mathrm{~nm}$ ) was increased in four steps from 0 to $320 \mathrm{~W} \mathrm{~m}^{-2}$. In series $\mathrm{II} \mathrm{CO}_{2}$ response was measured at a constant irradiance of 0 or $320 \mathrm{~W} \mathrm{~m}^{-2}$. For both irradiances the ambient $\mathrm{CO}_{2}$ concentration was increased from 340 to 600 $\mathrm{mg} \mathrm{m}^{-3}$ and finally to $1000 \mathrm{mg} \mathrm{m}^{-3}$. In both series, air temperature was approximately $20^{\circ} \mathrm{C}$ and air humidity was 12 mbar.

Measurement of mildew infection. The total leaf area and the area covered by mildew lesions on both upper and lower leaf surface were measured. The margin of 
leaf discoloration around mildew hyphae was taken to be the limit of a lesion. From these data the percentage mildew infected leaf area (PMI) was calculated.

\section{Results and discussion}

The assimilation rate at different irradiances, in series I, is best described by a negative exponential light response curve (Goudriaan, 1982):

$\mathrm{A}=(\mathrm{AMAX}+\mathrm{RD}) *(1.0-\exp (-\mathrm{H} * \mathrm{EFF} /(\mathrm{AMAX}+\mathrm{RD})))-\mathrm{RD}$

where

$\mathrm{A}=$ net $\mathrm{CO}_{2}$ assimilation rate $\left(\mathrm{kg} \mathrm{CO}_{2} \mathrm{ha}^{-1} \mathrm{~h}^{-1}\right)$

AMAX $=\mathrm{CO}_{2}$ assimilation rate at light satiation $\left(\mathrm{kg} \mathrm{CO}_{2} \mathrm{ha}^{-1} \mathrm{~h}^{-1}\right)$

$\mathrm{RD}=$ dark respiration rate $\left(\mathrm{kg} \mathrm{CO}_{2} \mathrm{ha}^{-1} \mathrm{~h}^{-1}\right)$

$\mathrm{EFF}=$ initial light use efficiency $\left(\mathrm{kg} \mathrm{CO}_{2} \mathrm{ha}^{-1} \mathrm{~h}^{-1} \mathrm{~W}^{-1} \mathrm{~m}^{2}\right)$

$\mathrm{H} \quad=$ absorbed radiation $(400-700 \mathrm{~nm})\left(\mathrm{W} \mathrm{m}^{-2}\right)$

Table 1. Normalized values of $\mathrm{CO}_{2}$ assimilation at light satiation (AMAX, in $\mathrm{kg} \mathrm{CO}_{2} \mathrm{ha}^{-1}$ $\mathrm{h}^{-1}$ ), light use efficiency (EFF in $\mathrm{kg} \mathrm{CO}_{2} \mathrm{ha}^{-1} \mathrm{~h}^{-1} \mathrm{~W}^{-1} \mathrm{~m}^{2}$ ) and dark respiration (RD in $\mathrm{kg}$ $\mathrm{CO}_{2} \mathrm{ha}^{-1} \mathrm{~h}^{-1}$ ), for the control plants at various development stages (DC).

\begin{tabular}{rccccccc}
\hline $\mathrm{n}^{1}$ & DC & AMAX & $\begin{array}{l}\text { SD } \\
( \pm)\end{array}$ & EFF & $\begin{array}{l}\text { SD } \\
( \pm)\end{array}$ & RD & $\begin{array}{l}\text { SD } \\
( \pm)\end{array}$ \\
11 & 32 & $100.0(45)^{2}$ & 3.9 & $100.0(.27)$ & 0.03 & $100.0(1.33)$ & 0.21 \\
4 & 59 & 96.3 & 3.2 & 103.4 & 0.03 & 78.2 & 0.23 \\
1 & 61 & 81.2 & & 99.3 & & 85.7 & \\
4 & 65 & 78.5 & 3.6 & 88.8 & 0.03 & 88.7 & 0.27 \\
3 & 69 & 82.9 & 4.5 & 89.9 & 0.01 & 88.7 & 0.14 \\
\hline
\end{tabular}

${ }^{1}$ Number of replicates, each replicate represents one assimilation-light response curve with four observations.

2 The mean value of the measurements for the plants in DC 32 is given between brackets.

The parameters AMAX, RD and EFF were iteratively determined using an optimization program (J. Goudriaan, pers.comm.). The values for AMAX, RD and EFF for control plants of various development stages are given in Table 1. EFF is based on a computation with total global radiation. When Photosynthetic Active Radiation (PAR) is used, multiplication with 1.41 is necessary. AMAX decreased with increasing development stage ( $\alpha=0.1$ ) (Fig. 1). There was no significant effect of the development stage on EFF and RD at the same level of confidence $(\alpha=0.1$ and 0.2 , respectively).

The parameters for mildew-infected plants (DC 32), grouped in classes of PMI, are given in Table 2. AMAX was strongly reduced by mildew infection, the marginal effect being largest at low values of PMI (Fig. 2). There was no significant effect of mildew on EFF or RD $(\alpha=0.1)$, although there was a tendency for EFF to decrease and for RD to increase (Fig. 3). This tendency was absent in the control plants. 


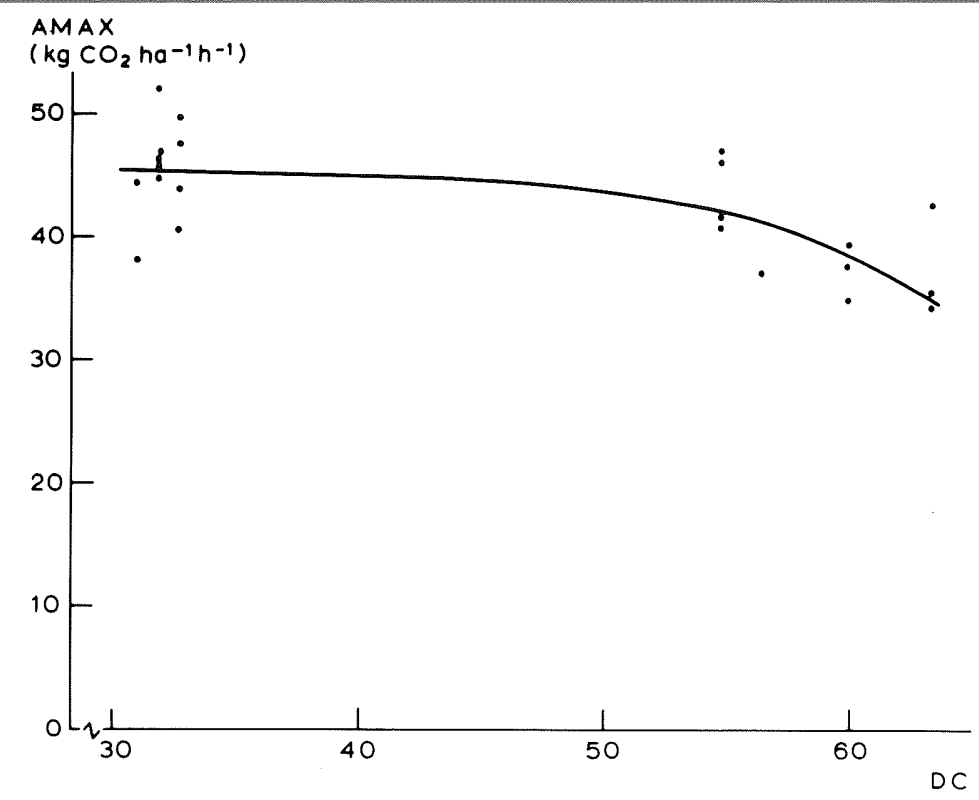

Fig. 1. $\mathrm{CO}_{2}$ assimilation rate at light satiation (AMAX) (in $\mathrm{kg} \mathrm{CO}_{2} \mathrm{ha}^{-1} \mathrm{~h}^{-1}$ ) at different crop development stages (DC), in ambient air $\left(340 \mathrm{mg} \mathrm{m}^{-3} \mathrm{CO}_{2}\right)$.

Table 2. Normalized values of maximum assimilation rate (AMAX in $\mathrm{kg} \mathrm{CO}_{2} \mathrm{ha}^{-1} \mathrm{~h}^{-1}$ ), light use efficiency (EFF, in $\mathrm{kg} \mathrm{CO}_{2} \mathrm{ha}^{-1} \mathrm{~h}^{-1} \mathrm{~W}^{-1} \mathrm{~m}^{2}$ ) and dark respiration (RD, in $\mathrm{kg} \mathrm{CO}_{2}$ $\left.\mathrm{ha}^{-1} \mathrm{~h}^{-1}\right)$. Mildew infected-plants were grouped in classes of percentage mildew infected leaf area (PMI).

\begin{tabular}{rllllllll}
\hline $\mathrm{n}^{1}$ & PMI class & AMAX & $\begin{array}{l}\text { SD } \\
( \pm)\end{array}$ & EFF & $\begin{array}{l}\text { SD } \\
( \pm)\end{array}$ & RD & $\begin{array}{l}\text { SD } \\
( \pm)\end{array}$ \\
11 & control & $100.0^{2}(45)^{3}$ & 3.9 & $100.0(.27)$ & 0.02 & $100.0(1.33)$ & 0.21 \\
11 & $0.1-0.5$ & 97.1 & 4.4 & 101.5 & 0.03 & 94.0 & 0.20 \\
11 & $0.5-1.0$ & 86.5 & 4.1 & 100.4 & 0.03 & 99.2 & 0.29 \\
9 & $1.0-2.0$ & 83.6 & 4.9 & 103.4 & 0.02 & 111.3 & 0.37 \\
9 & $2.0-3.0$ & 66.8 & 4.1 & 94.0 & 0.03 & 109.8 & 0.25 \\
10 & $3.0-6.0$ & 57.5 & 5.2 & 88.8 & 0.04 & 128.6 & 0.29 \\
9 & $6.0-10.0$ & 55.3 & 4.9 & 84.7 & 0.03 & 123.3 & 0.23 \\
8 & $\geqslant 10.0$ & 40.1 & 2.6 & 86.2 & 0.03 & 133.8 & 0.42 \\
\hline
\end{tabular}

1 Number of replicates.

2 Age effects are eliminated, see Table 1.

${ }^{3}$ Measured values for the control are given between brackets. 

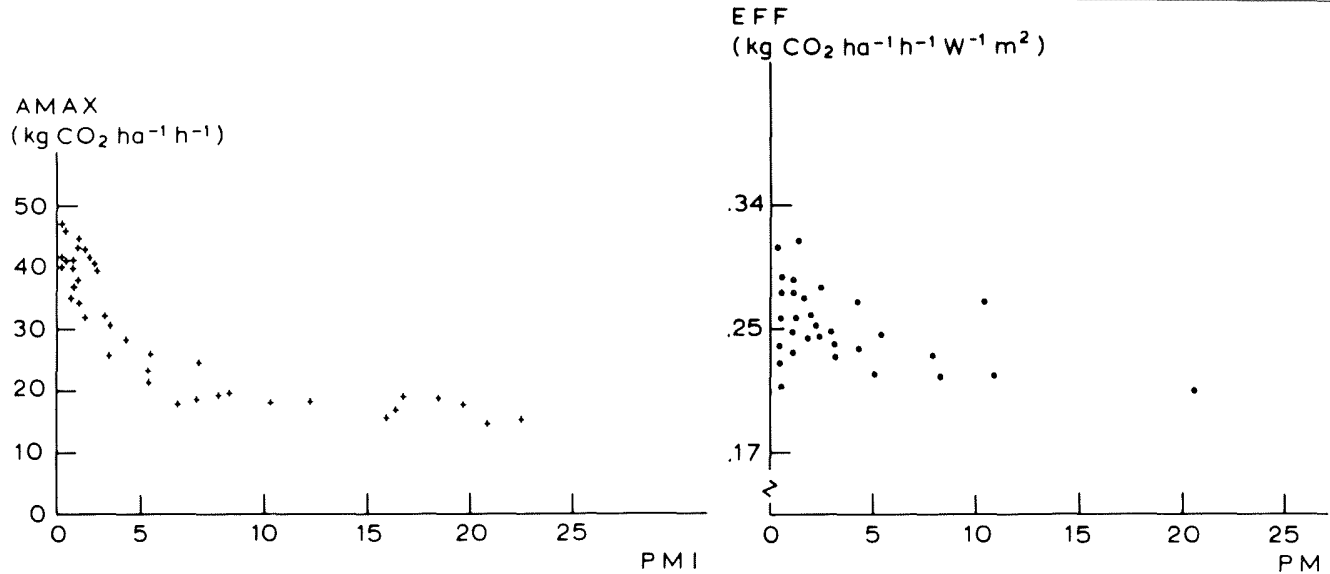

Fig. 2. $\mathrm{CO}_{2}$ assimilation rate at light satiation (AMAX) (in $\mathrm{kg} \mathrm{CO}_{2} \mathrm{ha}^{-1} \mathrm{~h}^{-1}$ ) at different mildew infection levels (PMI) in ambient air (340 $\mathrm{mg} \mathrm{m}^{-3} \mathrm{CO}_{2}$ ), at crop development stages <DC 60 .

Fig. 3. Initial light use efficiency of $\mathrm{CO}_{2}$ assimilation rate (EFF) (in $\mathrm{kg} \mathrm{CO}_{2} \mathrm{ha}^{-1} \mathrm{~h}^{-1}$ $\mathrm{W}^{-1} \mathrm{~m}^{2}$ ) at different mildew infection levels (PMI) in ambient air $\left(340 \mathrm{mg} \mathrm{m}^{-3} \mathrm{CO}_{2}\right)$, al crop development stages <DC 60 .

Table 3. The ratio of assimilation (A) and transpiration rates $(\mathrm{T})$ at an irradiance of $320 \mathrm{~W}$ $\mathrm{m}^{-2}$ and ambient $\mathrm{CO}_{2}$ concentration of $340 \mathrm{mg} \mathrm{m}^{-3}$ for control and mildew-infected plants at DC 50 .

\begin{tabular}{rlrl}
\hline $\mathrm{n}^{1}$ & PMI class & A/T & $\begin{array}{l}\text { SD } \\
\pm\end{array}$ \\
& & & \\
23 & control & 10.6 & 0.95 \\
11 & $0.1-0.5$ & 10.4 & 1.07 \\
11 & $0.5-1.0$ & 9.3 & 0.67 \\
9 & $1.0-2.0$ & 9.2 & 0.65 \\
9 & $2.0-3.0$ & 9.4 & 0.80 \\
10 & $3.0-6.0$ & 9.3 & 0.81 \\
9 & $6.0-10.0$ & 9.6 & 0.74 \\
8 & $\geqslant 10.0$ & 8.9 & 0.53 \\
\hline
\end{tabular}

${ }^{1}$ Number of replicates.

The transpiration rate of mildew-infected plants was also much lower than that of control plants, at all development stages. This effect was similar to the reduction of assimilation rate at light satiation. The assimilation rate/transpiration rate ratio $(\mathrm{A} / \mathrm{T})$ was, therefore, not significantly affected by mildew infestation (Table 3 ).

The simultaneous reduction of assimilation and transpiration rates may have been caused by two different mechanisms: one based on an increase in carboxylation resistance, and a second based on an increase in stomatal resistance. This is illustrated Neth. J. Pl. Path. 91 (1985) 


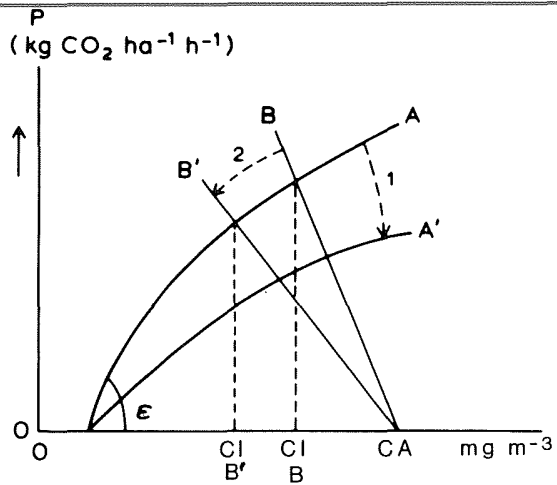

Fig. 4. Assimilation rate $(\mathrm{P})$ at various internal $\mathrm{CO}_{2}$ concentrations ( $\mathrm{CI}$, curve $\mathrm{A})$; and the $\mathrm{CO}_{2}$ supply function at various internal $\mathrm{CO}_{2}$ concentrations (line B). Effects of mildew are indicated for two hypothetical mechanisms: (1) Reduction in efficiency in $\mathrm{CO}_{2}$ absorption ( () ): curve $\mathrm{A}$ transforms into curve $\mathrm{A}^{\prime}$. (2) Increase in stomatal resistance: line $\mathrm{B}$ transforms into line $\mathrm{B}^{\prime}$.

in Fig. 4. Curve $A$ represents the response of assimilation rate $(\mathrm{P})$ to the internal $\mathrm{CO}_{2}$ concentration $(\mathrm{CI})$. Line $\mathrm{B}$ is the $\mathrm{CO}_{2}$ supply function, describing the diffusion of $\mathrm{CO}_{2}$ from the atmosphere (with concentration $\mathrm{CA}$ ) to the intercellular spaces (with concentration $\mathrm{CI}$ ). The initial slope made by curve $\mathrm{A}$ with the abscissa $(\varepsilon)$ represents the efficiency of $\mathrm{CO}_{2}$ use, i.e. the inverse of carboxylation resistance.

If the first mechanism was operating (1), then the $\mathrm{CO}_{2}$ flow from the stomatal cavities to the carboxylation sites should decrease. Because of the feedback loop between internal $\mathrm{CO}_{2}$ concentration, assimilation rate and stomatal conductivity, the stomata would close (Goudriaan and Van Laar, 1978; Bell, 1982; Farquhar and Sharkey, 1982). Consequently, the rates of gas exchange would be reduced.

This mechanism was investigated by measuring the $\mathrm{CO}_{2}$ response of assimilation rate (experiment series II). Carboxylation resistance was calculated from the relation between internal $\mathrm{CO}_{2}$ concentration $(\mathrm{CI})$ and net assimilation rate at an irradiance of $320 \mathrm{~W} \mathrm{~m}^{-2}$ (Goudriaan, 1982). Analogous to the light response of $\mathrm{CO}_{2}$ assimilation, this relation is best described by

$\mathrm{P}=\operatorname{PMAX} *(1.0-\exp ((\mathrm{CI}-\mathrm{CC}) * \varepsilon / \mathrm{PMAX}))$

where

$\mathrm{P} \quad=$ net assimilation rate $\left(\mathrm{kg} \mathrm{CO}_{2} \mathrm{ha}^{-1} \mathrm{~h}^{-1}\right)$

PMAX $=$ maximum net assimilation rate $\left(\mathrm{kg} \mathrm{CO}_{2} \mathrm{ha}^{-1} \mathrm{~h}^{-1}\right)$

$\mathrm{CI}=$ internal $\mathrm{CO}_{2}$ concentration $\left(\mathrm{mg} \mathrm{m}^{-3}\right)$

$\mathrm{CC}=\mathrm{CO}_{2}$ compensation point $\left(\mathrm{mg} \mathrm{m}^{-3}\right)$

$\varepsilon=$ efficiency of $\mathrm{CO}_{2}$ use $\left(\mathrm{m} \mathrm{s}^{-1}\right)$

The carboxylation resistance is represented by $\varepsilon^{-1}\left(\mathrm{~s} \mathrm{~m}^{-1}\right)$. The $\mathrm{CI}$ response curves of the assimilation rates of diseased and control plants are presented in Fig. 5. The parameters of the curves are given in Table 4 . The value of $\varepsilon$ was significantly lowered by mildew infection, indicating an increased carboxylation resistance for mildew infected plants. 


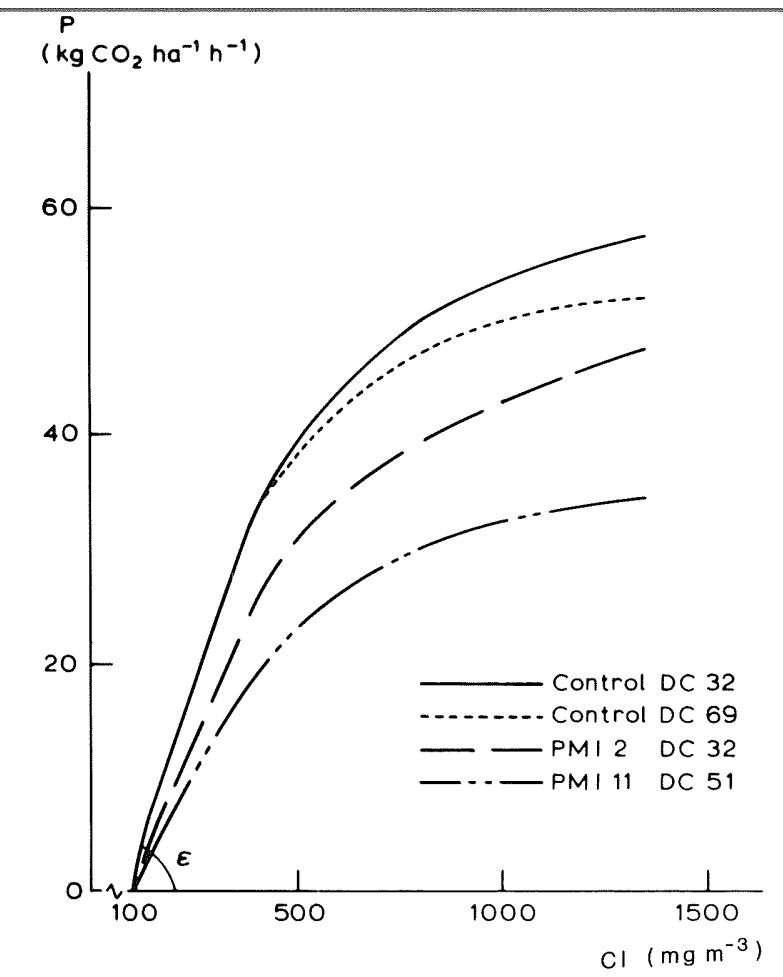

Fig. 5. Assimilation rate of diseased and control plants (P) (in $\mathrm{kg} \mathrm{CO}_{2}$ $\left.\mathrm{ha}^{-1} \mathrm{~h}^{-1}\right)$ at different computed internal $\mathrm{CO}_{2}$ concentrations $(\mathrm{CI})$ in $\mathrm{mg} \mathrm{m}^{-3}$.

Table 4. Parameters of $\mathrm{CO}_{2}$ response curves at various development stages (DC) of control and mildew-infected plants at various infection levels (PMI): maximum net assimilation rate (PMAX, in $\mathrm{kg} \mathrm{CO}_{2} \mathrm{ha}^{-1} \mathrm{~h}^{-1}$ ) and efficiency of $\mathrm{CO}_{2}$ use $\left(\varepsilon\right.$, in $\left.\mathrm{m} \mathrm{s}^{-1}\right)$. Irradiance was $320 \mathrm{~W}$ $\mathrm{m}^{-1}$.

\begin{tabular}{llllll}
\hline $\mathrm{n}^{1}$ & DC & PMI & PMAX & $\mathcal{E}$ & $\mathrm{r}^{22}$ \\
2 & 32 & 0.0 & 52.9 & 0.0047 & 0.983 \\
2 & 69 & 0.0 & 48.6 & 0.0048 & 0.950 \\
6 & 32 & 2.0 & 45.7 & 0.0033 & 0.981 \\
1 & 59 & 7.5 & 45. & 0.0033 & 0.989 \\
1 & 59 & 4.4 & 42.8 & 0.0036 & 0.996 \\
1 & 51 & 11.1 & 37.1 & 0.0038 & 0.957 \\
1 & 55 & 20.1 & 34.6 & 0.0025 & 0.999 \\
1 & 65 & 8.1 & 34.6 & 0.0020 & 0.999 \\
\hline
\end{tabular}

1 Number of replicates, each replicate represents one assimilation-light response curve with four observations.

${ }^{2}$ Square of correlation of coefficient.

The second mechanism of gas exchange reduction (2) would be expressed as a reduction of the CI/CA ratio (see Fig. 4). In Table 5 the CI/CA ratio is given for mildewinfected and control plants, with an irradiance of $320 \mathrm{~W} \mathrm{~m}^{-2}$. Mildew had no significant effect on the ratio, although the presence of mechanism 2 may have been masked Neth. J. Pl. Path. 91 (1985) 
Table 5. The ratio (CI/CA) of the internal $\mathrm{CO}_{2}$ concentration $(\mathrm{Cl})$ to the ambient $\mathrm{CO}_{2}$ concentration (CA), for control and mildew-infected plants at development stages DC 32 and DC 55.

\begin{tabular}{|c|c|c|c|c|c|c|c|}
\hline \multirow[t]{2}{*}{ Plants } & \multirow[t]{2}{*}{$n^{1}$} & \multicolumn{2}{|c|}{$\mathrm{CA}=340 \mathrm{mg} \mathrm{m}^{-3}$} & \multicolumn{2}{|c|}{$\mathrm{CA}=600 \mathrm{mg} \mathrm{m}^{-3}$} & \multicolumn{2}{|c|}{$\mathrm{CA}=1000 \mathrm{mg} \mathrm{m}^{-3}$} \\
\hline & & $\mathrm{CI} / \mathrm{CA}$ & SD & $\mathrm{CI} / \mathrm{CA}$ & SD & $\mathrm{Cl} / \mathrm{CA}$ & SD \\
\hline DC 32: control & 2 & 0.77 & 0.007 & 0.77 & 0.007 & 0.79 & 0.028 \\
\hline mildew infected & 6 & 0.73 & 0.049 & 0.74 & 0.023 & 0.78 & 0.033 \\
\hline DC 55: control & 2 & 0.74 & 0.014 & 0.73 & 0.021 & 0.71 & 0.049 \\
\hline mildew infected & 5 & 0.73 & 0.021 & 0.72 & 0.029 & 0.70 & 0.016 \\
\hline
\end{tabular}

${ }^{1}$ Number of replicates.

by the strong effects of mechanism 1. It is concluded that there is no influence of mildew on stomatal regulation mechanism. As a result, the efficiency of water use, expressed as the assimilation/transpiration ratio, is barely influenced by mildew.

Simulation. To evaluate the effect of mildew on the gross assimilation rate of a crop, the relation between percentage mildew (PMI), AMAX (Equation 3) and development stage (DC) was incorporated in the simulation model CROPPHOT (Goudriaan and Van Laar, 1978). A relation was derived from the measured data through an optimization procedure:

$\operatorname{AMAX}=-28+\frac{87}{3.1+\mathrm{PMI}}+\frac{45}{1+\mathrm{e}^{0.13 * \mathrm{DC}-10.4}}$

The model calculates the daily gross assimilation in $\mathrm{kg}$ dry matter ha ${ }^{-1}$. The simulation model was run for various development stages, assuming a homogeneous vertical distribution of mildew in the crop. The results of these simulations are presented in Table 6. Under a clear sky there was a superproportional reduction of gross assimilation rate by mildew. Under an overcast sky the effect was much smaller. The reduction in gross assimilation rate was smaller than the reduction in AMAX.

A homogeneous distribution of mildew will be rarely met in practice. More often the infection is located initially in the lower leaf layers, and spreads from the bottom to the top of the canopy. The effect of the location of infection was simulated assuming overall values of PMI as before but with the mildew concentrated in specific leaf layers of the canopy. The results are presented in Table 7.

Gross assimilation was most markedly reduced when the mildew was uniformly distributed over the canopy or concentrated in the upper leaf layers. When the mildew was concentrated in lower leaf layers the reduction was smaller, and the effect of variation in the amount of the mildew was substantial only when levels above $4 \%$ were reached. Due to the light extinction within the canopy, the assimilation rate of lower leaf layers was not at light satiation level. Since only the assimilation rate at light satiation was affected by mildew, in this simulation the reduction in the assimilation rate of the lower leaf layers was limited. 


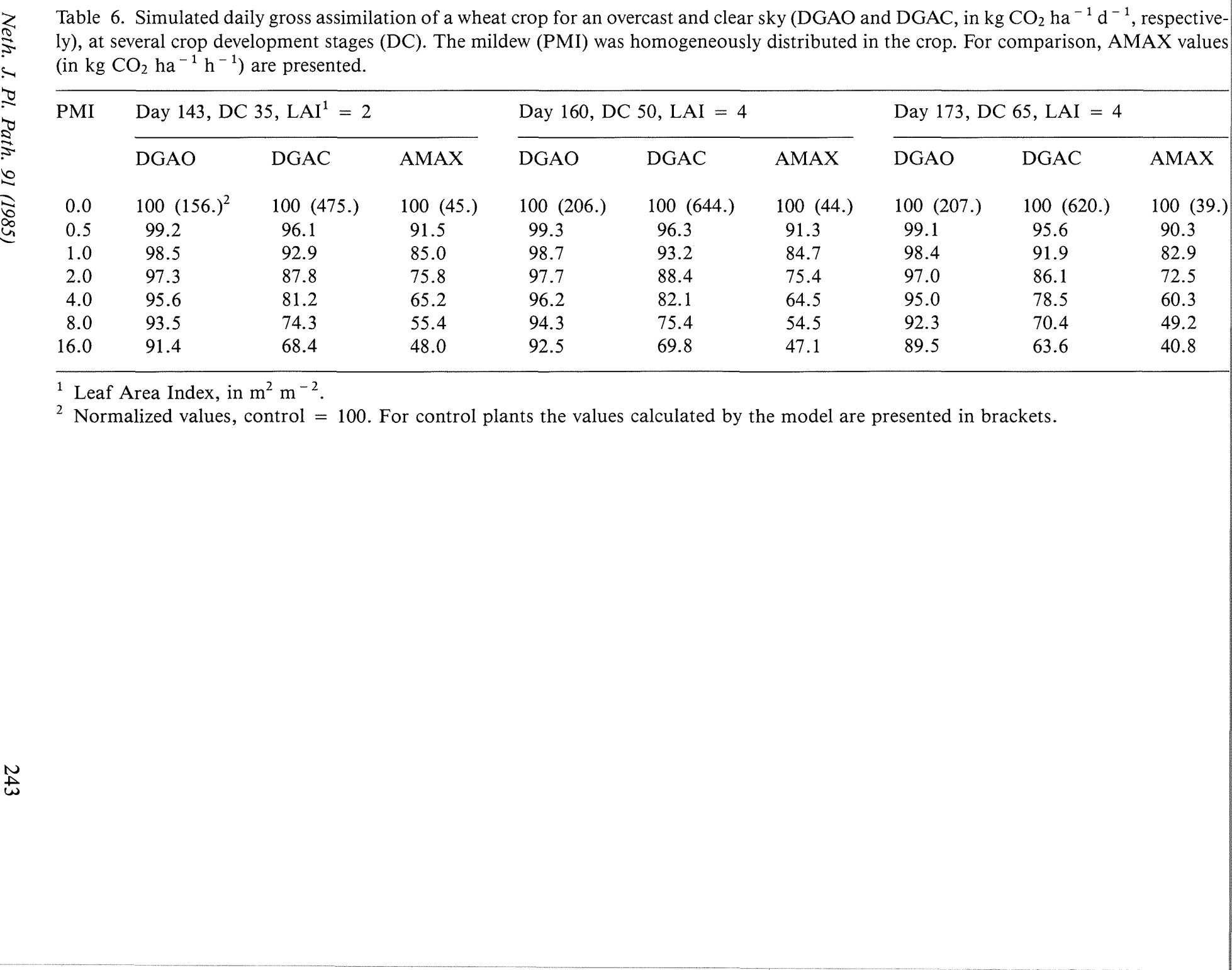


Table 7. Location effect of mildew infection on daily gross assimilation under an overcast sky (DGAO) and under a clear sky (DGAC) for crops with $\mathrm{LAI}^{1}=2$ (DC 35) and LAI $=4$ (DC 50). Starting from the top, leaf layers (LAI $=1$ per layer) are numbered I to IV. The percentage mildew covered leaf area (PMI) and AMAX (in $\mathrm{kg} \mathrm{CO}_{2} \mathrm{ha}^{-1} \mathrm{~h}^{-1}$ ) of the diseased layers are represented by PMIL and AMAXL, respectively.

\begin{tabular}{|c|c|c|c|c|c|c|c|c|}
\hline \multirow{2}{*}{$\begin{array}{l}\text { Infected } \\
\text { leaf layers }\end{array}$} & \multicolumn{4}{|c|}{$\mathrm{PMI}=4$} & \multicolumn{4}{|c|}{$\mathrm{PMI}=8$} \\
\hline & PMIL & $\mathrm{AMAXL}^{2}$ & $\mathrm{DGAO}^{2}$ & $\mathrm{DGAC}^{2}$ & PMIL & $\mathrm{AMAXL}^{2}$ & $\mathrm{DGAO}^{2}$ & $\mathrm{DGAC}^{2}$ \\
\hline \multicolumn{9}{|c|}{$\mathrm{LAI}=2, \mathrm{DC} 35:$} \\
\hline none & 0 & 100 & 100 & 100 & 0 & 100 & 100 & 100 \\
\hline I & 8 & 55 & 95 & 82 & 16 & 48 & 93 & 78 \\
\hline II & 8 & 55 & 99 & 92 & 16 & 48 & 98 & 90 \\
\hline all & 4 & 65 & 96 & 81 & 8 & 55 & 93 & 74 \\
\hline \multicolumn{9}{|c|}{$\mathrm{LAI}=4, \mathrm{DC} 50$} \\
\hline none & 0 & 100 & 100 & 100 & 0 & 100 & 100 & 100 \\
\hline I & 16 & 47 & 95 & 83 & 32 & 42 & 94 & 81 \\
\hline $\mathrm{I}+\mathrm{II}$ & 8 & 55 & 95 & 80 & 16 & 47 & 93 & 75 \\
\hline IV & 16 & 47 & 100 & 98 & 32 & 42 & 100 & 98 \\
\hline IV + III & 8 & 55 & 100 & 96 & 16 & 47 & 100 & 95 \\
\hline IV + III + II & 5.3 & 60 & 99 & 91 & 10.7 & 51 & 98 & 88 \\
\hline all & 4 & 65 & 96 & 82 & 8 & 55 & 95 & 75 \\
\hline
\end{tabular}

${ }^{1}$ Leaf Area Index, in $\mathrm{m}^{2} \mathrm{~m}^{-2}$.

${ }^{2}$ Normalized values; disease-free $=100$.

When mildew was present only in the lower leaf layers, the LAI (Leaf Area Index, $\mathrm{m}^{2} \mathrm{~m}^{-2}$ ) of the crop was an important factor in the amount of assimilation reduction. With a small LAI, the low leaf layers produce assimilates at a higher rate than when the LAI is large. Consequently the presence of mildew in the lowest leaf layer of a lowLAI crop would result in a larger reduction of assimilation than would the same level of infection in a high-LAI crop.

Although there was no significant effect of mildew infection on light use efficiency (EFF), the effect of mildew infection on EFF (Fig. 3) $(\mathrm{EFF}=0.034 * \mathrm{PMI}+0.27$ ) was nevertheless studied by simulation, in the same way as the effect of mildew infection on AMAX. In Table 8 the results of the computations for the combined effects on AMAX and EFF are given. Unlike a reduction of AMAX, which affects assimilation only at high irradiance, a reduction of EFF and AMAX reduced assimilation over the total range of irradiances. As a consequence the effects on daily gross assimilation rate were considerably larger. Again, the effects of the distribution of mildew over the canopy were simulated. The results of these computations (Table 9) demonstrate that a homogeneously distributed infection had a much larger effect than would a similar level of attack present only in the lower leaf layers. The results of these simulations correspond with field experiments (R.A. Daamen, in prep.) in which a clear location effect has been demonstrated. 

$\mathrm{W}^{-1} \mathrm{~m}^{2}$ ) by mildew infection, coupled with a reduction of maximal assimilation rate (AMAX, in $\mathrm{kg} \mathrm{CO}_{2} \mathrm{ha}^{-1} \mathrm{~h}^{-1}$ ), on daily gross assimilation under an overcast sky (DGAO) and under a clear sky (DGAC) (kg CO ha $\mathrm{ha}^{-1}$ ). Crop development stage DC 50, $\mathrm{LAI}^{1}=4$. Homogeneous mildew distribution (PMI) over the leaf layers.

\begin{tabular}{rcccc}
\hline PMI & AMAX $^{2}$ & EFF $^{2}$ & DGAO $^{2}$ & DGAC $^{2}$ \\
0.0 & $100(44)$ & $100(.27)$ & $100(206)$ & $100(644)$ \\
0.5 & 91 & 99 & 99 & 96 \\
1.0 & 85 & 99 & 98 & 83 \\
2.0 & 75 & 97 & 95 & 87 \\
4.0 & 65 & 95 & 92 & 80 \\
8.0 & 55 & 90 & 86 & 72 \\
16.0 & 47 & 79 & 76 & 63 \\
\hline
\end{tabular}

${ }^{1}$ Leaf Area Index, in $\mathrm{m}^{2} \mathrm{~m}^{-2}$.

${ }^{2}$ Normalized values at 100 when PMI $=0$; figures in brackets were calculated by the model.

Table 9. As Table 8, but mildew infection concentrated in lower leaf layers. PMIL, AMAXL and EFFL are percentage mildew infected leaf area, maximum assimilation rate and light use efficiency of the diseased layers, respectively.

\begin{tabular}{lccccc}
\hline PMI & PMIL & AMAXL $^{1}$ & EFFL $^{1}$ & DGAO $^{1}$ & DGAC $^{1}$ \\
0. & 0. & $100(44)$ & $100(.27)$ & $100(206)$ & $100(644)$ \\
2. & 4. & 65 & 95 & 95 & 94 \\
4. & 8. & 55 & 90 & 90 & 90 \\
8. & 16. & 47 & 79 & 80 & 82
\end{tabular}

$\overline{1}$ Normalized values at 100 when PMI $=0$; figures in brackets were calculated by the model.

Conclusions. This study demonstrates that mildew caused a strong reduction of the assimilation rate at light satiation (AMAX) and a tendency to reduce light use efficiency (EFF) of wheat leaves. There was no significant effect on dark respiration (RD), although a tendency for an increase was present. This may be due to the respiration of the fungus or an increased plant respiration as a result of the presence of the fungus. The consequences of these effects for net assimilation are very small. This may be explained by the interdependence of AMAX and EFF in the optimization program. A considerable shift in AMAX will effect EFF, and vice versa. The $\mathrm{CO}_{2}$ responses of control and infected plants make it clear that the reduction of AMAX is caused by an increased carboxylation resistance, indicating an inhibition of carboxylation processes by mildew.

Transpiration rate was also strongly reduced by mildew infection (Table 3). This reduction was correlated with the reduction of assimilation rate. The increase in the carboxylation resistance, as a result of mildew infection, lowers the $\mathrm{CO}_{2}$ flux from the stomatal cavities to the site of carboxylation. Stomata may close in response to this decreased $\mathrm{CO}_{2}$ use (Goudriaan and Van Laar, 1978), and this resulted in a decrease in the transpiration rate.

Neth. J. Pl. Path. 91 (1985) 

gross assimilation rate of a wheat crop was less strongly reduced by mildew infection than was AMAX. At low light intensities the relation between mildew infection severity and reduction of growth rate was almost linear. There was a strong location effect of mildew infection. Since light intensity in the canopy decreases exponentially with the number of leaf layers, lower leaves contribute less to daily production. Simulations demonstrate that a certain level of mildew infection, present only in the lower leaf layers, reduced daily gross assimilation less strongly than a homogeneous distribution of the same amount of mildew. This corresponds with field observations.

When water is not a limiting factor stomatal opening depends on the $\mathrm{CO}_{2}$ concentration in the intercellular spaces. With increased carboxylation resistance the $\mathrm{CO}_{2}$ flow is reduced. Stomata close, and consequently the transpiration rate falls. There was no direct effect of mildew on stomatal opening as described by Ayres (1978); closure of stomata was probably a result of increased carboxylation resistance, and was not due to a direct effect of the mildew infection.

Plants at development stages above DC 60 showed a reduction of AMAX irrespective of the presence of mildew infection. This observation is in agreement with results of De Vos (1975). Although direct photosynthesis measurements were not made on mildew-infected plants with development stages above DC 60, this effect was extrapolated to a mildew-infected wheat crop at DC 65 using the simulation model. The increase in carboxylation resistance which was demonstrated in the mildew-infected plants resulted in an earlier decrease of photosynthesis rate. This effect was similar to accelerated senescence mentioned by Finney (1979). Senescence is a result rather than a cause, of the shift in physiological response. Simulation of variation of mildew distribution in the canopy indicates an important location effect. Reduction of assimilation by mildew in low leaf layers was small compared to the reduction by mildew in high leaf layers. As a consequence of these results, both disease assessment methods and determination of the damage threshold should consider the location of mildew infection. There appears to be no fixed damage threshold; it is dependent on mildew distribution, on the LAI of the crop and on the crop development stage.

\section{Acknowledgements}

The experiments were performed with the help of Jelle Akkersdijk, Jet van Vrede and Co Sinke. Their contribution is gratefully acknowledged. Carel Hoveyn adviced with curve optimization and statistical interpretation. Jan Goudriaan and Gon van Laar contributed considerably in the analysis of the results and commented critically on earlier concepts of the manuscript. Bert van Amersfoort typed various versions of the paper.

\section{Samenvatting}

\section{Schadecomponenten van meeldauw in wintertarwe}

Bepalingen van fotosynthese en verdamping werden verricht bij verschillende ontwikkelingsstadia van wintertarwe, die in verschillende mate was aangetast door meeldauw. Zelfs bij vrij lage infectiepercentages (circa 4\%) was er al een aanzienlijke reductie van assimilatie en verdampingssnelheid bij lichtverzadiging. Lichtbenuttingsefficiëntie en 
De fysiologische achtergrond van deze effecten werd onderzocht door fotosynthesemetingen bij verschillende externe $\mathrm{CO}_{2}$ concentraties. Er werd aangetoond dat de carboxylatieweerstand werd verhoogd door meeldauwinfectie en dat de huidmondjesweerstand, grenslaagweerstand en transportweerstand in het mesofyl indirect werden beïnvloed.

De gevolgen van deze effecten op de dagelijkse groeisnelheid van een wintertarwegewas in verschillende ontwikkelingsfasen en met verschillende LAI werd nagegaan met een simulatiemodel. Deze berekeningen tonen aan dat een geringe meeldauwaantasting resulteert in een aanzienlijke reductie van de groeisnelheid van het gewas. Dit effect was duidelijker bij heldere dan bij bewolkte hemel.

\section{References}

Ayres, P.G., 1978. Water relations of diseased plants. In: Kozlowski, T.T., (Ed.), Water deficits and plant growth. Vol. V. Academic Press, London, p. 1-60.

Baenziger, P.S., Kilpatrick, R.A. \& Moseman, J.G., 1979. Reduced root and shoot growth caused by Erysiphe graminis tritici in related wheats grown in nutrient solution culture. Can. J. Bot. 57: 1345-1348.

Bell, C.J., 1982. A model of stomatal control. Photosynthetica 16: 486-495.

Farquhar, G.O. \& Sharkey, T.O., 1982. Stomatal conductance and photosynthesis. A. Rev. Pl. Physiol. 33: 317-345.

Finney, M.E., 1979. The influence of infection by Erysiphe graminis on the senescence of the first leaf of barley. Physiol. Pl. Path. 14: 31-36.

Goudriaan, J., 1982. Potential production processes. In: Penning de Vries, F.W.T. \& van Laar, H.H. (Eds), Simulation of plant growth and crop production. Pudoc, Wageningen, p. 98-113.

Goudriaan, J. \& van Laar, H.H., 1978. Calculation of daily totals of the gross $\mathrm{CO}_{2}$-assimilation of leaf canopies. Neth. J. agric. Sci. 26: 373-383.

Large, E.C. \& Doling, D.A., 1962. The measurement of cereal mildew and its effect on yield. Pl. Path. 11: 47-57.

Large, E.C. \& Doling, D.A., 1963. Effect of mildew on yield of winter wheat. Pl. Path. 12: $128-130$.

Louwerse, W. \& Oorschot, J.L.P. van, 1969. An assembly for routine measurements of photosynthesis, respiration and transpiration of intact plants under controlled conditioning. Photosynthetica 3: 305-315.

Martin, J.T., Stuckey, R.E., Safir, G.R. \& Ellingboe, A.E., 1975. Reduction of transpiration from wheat caused by germinating conidia of Erysiphe graminis f.sp. tritici. Physiol. Pl. Path. 7: 71-77.

Paulech, C., 1966. Photosynthesis and respiration of barley while being actually infected by powdery mildew. Biologia (Bratislava) 21: 321-328.

Priehradny, S., 1978. Dynamics of the ratio of daily uptake and loss of water in barley infected by Erysiphe graminis. Biologia (Bratislava) 33: 57-63.

Scott, K.J. \& Smillie, R.M., 1966. Metabolic regulation in diseased leaves. I. The respiratory rise in barley leaves infected with powdery mildew. Pl. Physiol. Lancaster 41: 289-297.

Vizarova, G. \& Minarçic, P., 1974. The influence of powdery mildew upon the cytokinins and the morphology of barley roots. Phytopath. Z. 81: 49-55.

Vos, N.M. de, 1975. Field photosynthesis of winter wheat during the grain filling phase under highly fertile conditions. Proceedings of the second International Winter Wheat Conference, Zagreb, Yugoslavia: 251-255.

Zadoks, J.C., Chang, T.T. \& Konzak, C.F., 1974. A decimal code for the growth stages of cereals. Weed Res. 14: 415-421.

Neth. J. Pl. Path. 91 (1985) 



\section{ERRATUM}

Due to changes in various versions of the manuscript there is a major mistake in the legends to the figures and at various places in the text. The concentrations of $\mathrm{CO}_{2}$ is expressed in $\mathrm{mg} \mathrm{m}^{-3}$ but should be expressed as ppm, with the exception of Figure 5. So all $\mathrm{CO}_{2}$ concentrations are in $\mathrm{ppm}$. 